\title{
Why was Darwin's view of species rejected by twentieth century biologists?
}

\author{
James Mallet
}

Published online: 1 May 2010

(C) Springer Science+Business Media B.V. 2010

\begin{abstract}
Historians and philosophers of science agree that Darwin had an understanding of species which led to a workable theory of their origins. To Darwin species did not differ essentially from 'varieties' within species, but were distinguishable in that they had developed gaps in formerly continuous morphological variation. Similar ideas can be defended today after updating them with modern population genetics. Why then, in the 1930s and 1940s, did Dobzhansky, Mayr and others argue that Darwin failed to understand species and speciation? Mayr and Dobzhansky argued that reproductively isolated species were more distinct and 'real' than Darwin had proposed. Believing species to be inherently cohesive, Mayr inferred that speciation normally required geographic isolation, an argument that he believed, incorrectly, Darwin had failed to appreciate. Also, before the sociobiology revolution of the 1960s and 1970s, biologists often argued that traits beneficial to whole populations would spread. Reproductive isolation was thus seen as an adaptive trait to prevent disintegration of species. Finally, molecular genetic markers did not exist, and so a presumed biological function of species, reproductive isolation, seemed to delimit cryptic species better than character-based criteria like Darwin's. Today, abundant genetic markers are available and widely used to delimit species, for example using assignment tests: genetics has replaced a Darwinian reliance on morphology for detecting gaps between species. In the 150th
\end{abstract}

J. Mallet

Wissenschaftskolleg zu Berlin, Wallotstraße 19, 14193 Berlin, Germany

J. Mallet

Radcliffe Institute, Harvard University, Byerly Hall, 8 Garden St., Cambridge, MA 02138, USA

J. Mallet $(\bowtie)$

Galton Laboratory, Department of Genetics, Evolution and Environment, University College London, 4 Stephenson Way, London NW1 2HE, UK

e-mail: j.mallet@ucl.ac.uk 
anniversary of The Origin of Species, we appear to be returning to more Darwinian views on species, and to a fuller appreciation of what Darwin meant.

Keywords Darwin - Species concept - Essentialism - Levels of selection · Group selection · Holism

\section{Introduction}

What is a species? This paper investigates the common belief of biologists, for at least 70 years, that Darwin did not define and did not have a useful concept of species. He is accused of failing to have addressed even the question posed by the title of his 1859 book On the Origin of Species (Mayr 1942, 1963; Futuyma 1986, 1998; Coyne and Orr 2004; Coyne 2009; Berry and Hoekstra 2009).

Darwin's work is often combed for new information, and historians and philosophers of science now see his view of species in The Origin as effective for his purposes (Lovejoy 1968a; Ghiselin 1969; Kottler 1978; Beatty 1985; McOuat 1996; Stamos 2006; Kohn 2009; Ereshefsky 2009; Sloan 2009). Many of today's biologists support a concept of species as reproductively isolated entities, but genetic evidence for continuity between varieties and species in nature is abundant, very much as Darwin had argued, both for geographically separated populations and also in overlap or sympatry (Mallet 2008a). Introgression and horizontal gene transfer among species means that the tree of life will not be entirely tree-like at the tips, but instead, strictly, a 'web of life' (Arnold 2006). Darwin's fluid approach to species nonetheless runs counter to many recent biologists, who have argued that species are sharply demarcated from subspecific varieties in nature, and are the only 'real' taxa (Dobzhansky 1935, 1937a, b, 1951; Mayr 1942, 1947, 1963; Coyne and Orr 2004).

In this paper, I investigate why Darwin's view of species was replaced, rather than becoming adapted for twentieth century evolutionary studies. One hundred and fifty years after the publication of The Origin, I suggest it is worth exploring a revisionist interpretation: that Darwin had a good idea of what he was talking about after all. I consider two related questions. Firstly, can we infer why Theodosius Dobzhansky, Ernst Mayr and others rejected the logic of Darwin's treatment of species (Ghiselin 1969; McOuat 1996; Ereshefsky 2009), and felt impelled to develop a new, anti-Darwinian definition? Secondly, what was the scientific and philosophical background of their time that influenced these biologists' approach?

\section{Darwin's view of species}

Darwin's straightforward view of species can be summed up:

Hereafter we shall be compelled to acknowledge that the only distinction between species and well-marked varieties is, that the latter are known, or 
believed, to be connected at the present day by intermediate gradations, whereas species were formerly thus connected (Darwin 1859: 485).

To Darwin, species form vague, human-defined, and difficult to discern waystations in evolution. They are detectable only by means of gaps in variation in a local area (i.e. in sympatry), as contrasted to continuous variation normally found among varieties within species. This should not be taken to mean that Darwin believed all species form a continuum with one another and with varieties:

To sum up, I believe that species come to be tolerably well-defined objects, and do not at any one period present an inextricable chaos of varying and intermediate links... (Darwin 1859: 177).

He merely felt that there is no clear boundary between species and varieties in doubtful cases, where varieties are evolving into species (see Appendix).

It is important to understand what Darwin was attempting to achieve. Firstly, he needed to disengage the operational, taxonomic basis of what scientists meant by species-distinguished by gaps in morphology — from their concept of them-the explanation or underlying reality of species: immutability and special creation. Secondly, he needed to convince his readers of his new explanation or concept of those operational entities - evolution. Much of the debate about Darwin's view of species hinges on whether he saw them as real, or whether he thought they didn't exist (Ereshefsky 2009). Darwin's stance has caused considerable confusion, because he had to argue, in a sense, for both. On the one hand, everyone, including Darwin himself, who had just completed a work on barnacle systematics, knows that species do exist, as evidenced by gaps in morphology in nature. This phenomenon of gaps is what his book set out to explain. On the other hand, since species evolve from varieties, there is no fundamental or essential difference between species and varieties, and there will always be arguments about borderline cases, about species in statu nascendi.

Thus Darwin saw no conflict in writing On the Origin of Species, a book which requires the existence of natural groups called species, and yet which also claims "no fundamental difference between varieties and species" (p. 278) and that their evolutionary explanation freed one "... from the vain search for the undiscovered and undiscoverable essence of the term species" (p. 485). He believed that species existed, but that they were not "fundamentally" different from varieties, and that they did not have "essences."

Darwin's view of species as populations becoming gradually separated by gaps in morphology seems naïve to a late twentieth/early twenty first century biologist because it apparently ignores obvious exceptions: that separate sexes or polymorphic forms (which have morphological gaps between them) can be conspecifics, that larvae belong to the same species as adults, or that reproductive isolation exists and is important in keeping species distinct, and so on. Needless to say, Darwin was aware of all of these, and they are all dealt with somewhere in The Origin, as has been pointed out by some historians of science (Ghiselin 1969; Kottler 1978; Sulloway 1979). Many biologists, on the other hand, were not convinced by Darwin's argument (e.g. Mayr 1959, 1963, 1982). 
In the first place, Darwin clearly understood the importance of intercrossing, 'gene flow' in today's terms, in impeding divergence in artificial and natural selection:

... we must not overrate the effects of intercrosses in retarding natural selection; for I can bring a considerable catalogue of facts, showing that within the same area, varieties of the same animal can long remain distinct, from haunting different stations, from breeding at slightly different seasons, or from varieties of the same kind preferring to pair together. (Darwin 1859: 103; see also p. 42)

The problem of intercrossing was extreme under Darwin's incorrect ideas of heredity, blending inheritance. Under Mendelian inheritance the situation improves, because underlying genetic variation is retained on intercrossing, even though maintaining divergent phenotypes remains a problem.

An understanding of intercrossing is necessary to appreciate the role of geography in speciation. Darwin recognized and clearly described how geographic isolation (also known as 'allopatry,' after Mayr 1942) would enhance divergent evolution by natural selection, and hence speciation by preventing the swamping effect of intercrossing (see also Sulloway 1979):

[Geographic] Isolation, also, is an important element in the process of natural selection. In a confined or isolated area... natural selection will tend to modify all the individuals of a varying species throughout the area in the same manner in relation to the same conditions. Intercrosses, also, with the individuals of the same species, which otherwise would have inhabited the surrounding and differently circumstanced districts, will be prevented (Darwin 1859: 104).

Darwin famously argued that speciation on large continents was more likely than on islands, but this view should not be interpreted as supporting purely sympatric (i.e. non-geographic) speciation (Sulloway 1979). Instead, Darwin argued, firstly, that there are more opportunities for environmental variation and temporary geographic isolation on continents than on remote islands. Secondly, more selectable variation (in today's terms, diversity originating by mutation) will arise in large continental populations because there are more possible individuals to vary. Thirdly, a greater diversity of variants will usually compete on re-establishing contact on continents, and in so doing, weaker variants will be filtered out more effectively. Poor competitors diverging as remote, isolated populations on islands, in contrast, would be unlikely to contribute as many daughter species to future successful populations (Bowler 2009):

Throughout, a great and open area, not only will there be a better chance of favourable variations arising from the large number of individuals of the same species there supported, but the conditions of life are infinitely complex from the large number of already existing species; and if some of these many species become modified and improved, others will have to be improved in a corresponding degree or they will be exterminated (Darwin 1859: 105-106). 
I conclude ... that for terrestrial productions a large continental area, which will probably undergo many oscillations of level, and which consequently will exist for long periods in a broken condition, will be the most favourable for the production of many new forms of life, likely to endure long and to spread widely (Darwin 1859: 107).

Darwin felt that geographic isolation was important in divergence, but he was arguing here against exactly the sorts of simple-minded and extreme ideas of allopatric 'Separationstheorie' proposed soon afterwards by Moritz Wagner (Wagner 1873, 1889) and supported by some recent authors (Mayr 1959, 1982; Coyne and Orr 2004). The Wagner affair is discussed further under Allopatric speciation below.

What to do about polymorphisms, larval phases, and separate sexes is flagged in Darwin's later chapter on classification:

... every naturalist has in fact brought descent into his classification; for he includes in his lowest grade, or that of a species, the two sexes; ... scarcely a single fact can be predicated in common of the males and hermaphrodites of certain cirripedes, when adult, and yet no one dreams of separating them. The naturalist includes as one species the several larval stages of the same individual, however much they may differ from each other and from the adult; as he likewise includes the so-called alternate generations of Steenstrup... He includes monsters; he includes varieties, not solely because they closely resemble the parent-form, but because they are descended from it (Darwin 1859: 424).

In 1871, Darwin discussed whether the races of man form a single or many species. $\mathrm{He}$ argued that the presence of morphological intermediates indicated a single human species, since human races intergraded at their boundaries wherever they met. He clearly implicated "mutual sterility" and "mutual repugnance to pairing" (in today's terms, reproductive isolation) as a cause of the separateness of species, but he differed from later authors by not using it as a definition of species:

... continued persistence without blending within the same area, is usually accepted as sufficient evidence, either of some degree of mutual sterility, or in the case of animals of some mutual repugnance to pairing.

Independently of fusion from intercrossing, the complete absence, in a wellinvestigated region, of varieties linking together any two closely-allied forms, is probably the most important of all the criterions of their specific distinctness; ... (Darwin 1871: 215)

Early Darwinians, such as Alfred Russel Wallace, Benjamin D. Walsh and Henry Walter Bates were all correspondents of Darwin's, and held very similar, Darwinian views of what they meant by species (Bates 1862; Walsh 1864; Wallace 1865). They all believed that speciation was caused by natural selection, and all were clearly aware of the importance of intercrossing in preventing divergence within species (Kottler 1978; Berlocher and Feder 2002). They clearly understood that its converse, now called 'reproductive isolation,' was a cause of species boundaries, 
but they didn't see the need to use it in a criterion for species. Many of their post1859 discoveries on mimicry and 'phytophagic varieties' were reported by Darwin in the sixth edition of The Origin (Darwin 1872). Darwin's botanical contacts Joseph Hooker and Asa Gray also understood and accepted Darwin's views on species (Gray 1888; Endersby 2008). All of these Darwinists simply addressed speciation in different terms than today: their aim was to elucidate any causes of divergence leading to separate species identified via gaps, rather than to attempt to unify species via a single explanation or essence, such as reproductive isolation (Mallet 2008c, 2009).

Darwin's new view of species in The Origin seemed, at least in the midnineteenth century, crucial to accepting 'transmutationism,' the evolutionary transition between species, as well as the proposed mechanism, natural selection, by which it occurred. Darwin needed to reject an alternative hypothesis, supported by Buffon, Lyell and others, that fixed species had been endowed by the Creator with an essential character of intersterility in order to prevent them from blending together (Lovejoy 1968b; Ghiselin 1969: 147-148; Beatty 1985). The biological basis of Buffon's understanding of species ${ }^{1}$ is closely related to today's reproductive isolation species definition (Coyne and Orr 2004), and it was Buffon's strict criterion that Darwin, as well as Lamarck before him, needed to disprove by citing examples of fertile species crosses in his chapter Hybridism (Lovejoy 1968a; Mallet 2008b). This was clearly Darwin's motivation in emphasising gaps in morphology rather than reproductive isolation (Ghiselin 1969; Sulloway 1979). It has been suggested that Darwin deliberately blurred the boundary between species and varieties in The Origin in order to make species seem more evolvable than they actually are (Beatty 1985). However, given that Darwin produced abundant factual documentation for his view of species, the idea that he hid his real views for purely tactical purposes is hard to sustain (see also McOuat 1996; Sloan 2009; Ereshefsky 2009).

Darwin's view of species as clusters of similar individuals separated by gaps remains relevant today. Species are multilocus genotypic clusters that retain identity when in sympatry with close relatives (Mallet 1995; Feder 1998; Coyne and Orr 2004). In sexual species, reproductive isolation of course helps to maintain this identity. However, above the species level, hybridization and introgression regularly occurs at low rates among species (Coyne and Orr 2004; Mallet 2005; Arnold 2006), and below the species level, ecotypes and ecological races are 'varieties' similar to species, except they engage in more frequent hybridization (Berlocher and Feder 2002; Drès and Mallet 2002; Mallet 2008a). Reproductive isolation thus is not suddenly complete at the species boundary, but merely declines approximately exponentially with genetic divergence across it (Gourbière and Mallet 2010). New statistical tests on abundant genetic data allow assignment of individuals to divergent populations, ecotypes or species (Pritchard et al. 2000): locally, species as genotypic clusters can be identified without knowledge of reproductive isolation.

\footnotetext{
1 For reviews of Buffon's own difficulties in applying this species concept, and the controversy over whether he was a special creationist, see Lovejoy (1968b) and Bowler (2003).
} 
Instead, for sexual organisms in sympatry, reproductive isolation can be inferred from the detection of distinct populations or multilocus clusters of genotypes.

Darwin's understanding of the counteracting effects of gene flow and geography on evolutionary divergence thus seem surprisingly modern to one reared on the myth of 'Darwin's failure' to define species. Given what we've noted, it seems unfair to say:

... Darwin failed to solve the problem indicated by the title of his work. ... In retrospect, it is apparent that Darwin's failure, as well as that of the antievolutionists, resulted to a large extent from a misunderstanding of the true nature of species (Mayr 1963: 12, 14).

What then caused biologists to fail to appreciate Darwin's view of species in the mid-twenteith century?

\section{Biology and the rejection of Darwin's species definition}

Before the 1930s, few had seemed troubled by Darwin's views on what species were. Biologists had mostly accepted evolution, but had been more concerned by, and indeed generally rejected his theory of evolution of species via natural selection. Special creation, 'mutation' (saltational Mendelian changes), orthogenesis and inheritance of acquired characteristics were all commonly entertained as mechanisms for the origin of species (Bowler 1992). The rediscovery of Mendelian genetics led to mutationist theories of speciation and was perhaps the most severe challenge to natural selection (de Vries 1909; Bateson 1909, 1913; see Bowler 1989). There seems to have been a brief flurry of rather 'modern' interest in the nature of species, geographic and non-geographic (i.e. ecological) isolation and the process of speciation in the 1890s to early 1900s (Poulton 1904; Jordan 1905a, b, 1905c; Britton 1908; Gulick 1908; Cook 1908; Bateson 1909), but it became subdued before and during World War I, before being revived again in the 1930s and 1940s. 'The species problem' referred then to the problem of how species evolved (Richards and Robson 1926; Robson 1928; Haldane 1932), rather than the problem of how to define species, as today.

Although some at this time wished for more concrete ideas of species based on 'physiological selection' (see below), most favoured a vaguely Darwinian view, of species not essentially different from varieties or subspecies, but separated by more distinct gaps (Wallace 1889; Bailey 1896; Britton 1908; Seward 1909; Robson 1928; Haldane 1932), regardless of the precise forces believed to lead to their evolution.

Changes in the philosophy of systematics

Theodosius Dobzhansky and Ernst Mayr were the two most important biologists in promoting, from the 1930s and 1940s onwards, a new view of species. These scientists ignored Darwin's attack on hybrid sterility as an essence of species and rejected his character-based view of species. They replaced it with their more 
concrete and explanatory 'biological concept,' based on a notion of reproductive isolation similar to the one Darwin had rejected.

Dobzhansky (1935) argued that there were really two concepts of species, a "static," taxonomic concept, and a "dynamic," genetic concept, that gave the species reality. Dobzhansky explained that the reality of the species category was due to isolating mechanisms, even though a requirement for interbreeding within species meant that asexuals, as well as groups within confusing plant genera such as Rubus, Hieracium, and Rosa, could not be classified as species. Dobzhansky's argument was greatly amplified by Mayr. He distinguished species taxa from the species category, as well as from the theoretical concept of species. Unfortunately, Mayr appears often to have used his terms somewhat interchangeably, and it has now been agreed by many, including Mayr himself (Mayr 1992a: 9, 2002), that his treatment in over 90 different publications of the concept versus taxon versus category question was confusing (Bock 1995; Ghiselin 2004a; Hey 2006; Haffer 2007).

Mayr, in addition, introduced the idea of 'population thinking,' which he distinguished from 'typological thinking' employed by creationists and taxonomists who ignored evolution; 'typology' was Mayr's much-used synonym for essentialism (Mayr 1982). 'Population thinking' has some subtle group-selectionist overtones, and this view accords with Mayr's positive reception of the holistic philosophy of Jan Smuts and others (Mayr 1982: 66; Haffer 2007: 38, 360-361). These distinctions are similar to Dobzhansky's ideas of dynamic ( $\sim$ population thinking) versus static species concepts ( typological thinking). Darwin, argued Mayr, introduced the world to the importance of population thinking, which depends on recognition of the central importance of population variation, in contrast to the typological idea that the 'essence' of a species was the important thing, and that the variation of actual individuals was trivial and unimportant. Mayr argued that his own reproductive isolation-based species concept was a product of population thinking, whereas creationist views of species were typological. Darwin had successfully introduced 'population thinking' to biology, but he still had a 'typological' species concept, according to Mayr:

Even Darwin, who was more responsible than anyone else for the introduction of population thinking into biology, often slipped back into typological thinking, for instance in his discussions on varieties and species (Mayr 1963: 6).

As well as supporting a concept of species based on reproductive isolation, Mayr strongly promoted a new practical approach to species taxa, known as 'polytypic species,' first introduced by entomologists and ornithologists of the period 18801910 (Stresemann 1975; Mayr 1982; Rothschild 1983; Mallet 2004, 2008b). Species were considered 'polytypic' because morphologically divergent geographic forms, interpreted as subspecies, could be included within the same species if they intergraded at mutual geographic boundaries, where they formed hybrid zones. These forms, hitherto often treated as good species, were granted validity as 'subspecies' under new rules of the International Commission of Zoological Nomenclature, leading to trinomial designations such as Troglodytes troglodytes 
troglodytes (the British subspecies of the European wren). Mayr referred to this taxonomic idea sometimes as the 'biological' species concept, and sometimes as the 'multidimensional' concept of species. At the same time, Mayr also agreed with Dobzhansky (1937b) and Poulton (1904) that the touchstone of species reality was the 'bridgeless gap' between species that overlap locally (in sympatry), an idea he called the 'nondimensional' concept of species, as well as confusingly, also, the 'biological species concept.'

The biological species concept, expressing a relation among populations, is meaningful and truly applicable only in the nondimensional situation. It can be extended to multidimensional situations only by inference (Mayr 1982: 273)

Today, it is simplest to interpret Mayr's philosophical ideas on species as follows (see especially Bock 1995; Haffer 2007: 208-216). The theoretical concept of species (as in the biological species concept) refers chiefly to the non-dimensional situation where good species are recognizable because they are reproductively isolated in sympatry. According to Mayr (see also Bock 1995; Coyne and Orr 2004), it is this concept that is most important in evolutionary biology. This principle can also provide some guidance in taxonomic decisions, in designating actual sympatric taxa as species. However, the principle fails when extended to populations that are distant or not in contact, whereupon some guesses about potential interbreeding must be used. It seems an attractive feature of reproductive isolation that it is experimentally verifiable (Dobzhansky 1935: 354); however sympatric species often hybridize in captivity that do not do so in the wild. Thus the entire category of actual species will include polytypic or multidimensional species taxa (individual instances of the species category) not readily delimited by the concept of reproductive isolation alone.

Some biologists and philosophers of science agree with Mayr that concepts and definitions with theoretical content are more important in science than mere criteria (Hull 1968; Ghiselin 1969; Bock 1995; de Queiroz 1998; Coyne and Orr 2004; Haffer 2007). For example, "the value of the biological species concept ... can be decided only by a consideration of its role within evolutionary theory, not by a consideration of systematic practice" (Bock 1995: 63). Others argue that loose, operational species criteria are more useful than theoretical definitions (Popper 1945: 19, 1972: 310; Dupré 1981, 1999; Kitcher 1984; Ruse 1987; Ereshefsky 1991, 2009; Smith 1994; Mallet 1995; Feder 1998; Hendry et al. 2000; Reydon 2004; Stamos 2006). From this viewpoint, Mayr, who felt he was waging war on essentialism with his typological/population thinking dichotomy, paradoxically seems to have promoted a new kind of essentialism. His theoretical concept of species reintroduced a reproductive isolation essence similar to the one Darwin had tried to banish. Deviations of actual organisms from idealized reproductive isolation thereby became less important than the underlying truth of the theoretical species concept.

Darwin's use of the term 'species' is very different. Darwin needed only criteria for distinguishing actual, taxonomic species in order to discuss how they evolved. The criteria were operational rather than theoretical (Ruse 1975; Ereshefsky 2009). It was only by using an operational definition, rather than a 
strictly evolution-oriented definition of species, that Darwin had been able to convince readers about evolution (Hull 1967; Ghiselin 1969; Sulloway 1979; Beatty 1985; McOuat 1996). Dobzhansky and Mayr, in contrast, were now dissatisfied with mere taxonomic criteria. Mayr in particular felt that the distinction between the theoretical species concept and actual species taxa was a major advance of 'modern' systematics. To them, a theoretical species concept was important in the study of evolution (e.g. Mayr 1982: 24), and should specify principles governing species existence: "A species concept is the description of the role a species plays in the household of nature" (Mayr 2002).

Physiological selection and isolating mechanisms

While the new philosophical approach to taxonomy undoubtedly played a role in leading to a rejection of Darwin's views, advances in other areas biology were perhaps more important. Dobzhansky and Mayr both trained relatively broadly as biologists, and the discussions of their day on the interface between genetics and systematics strongly influenced their beliefs about species. The 'modern synthesis' in genetics had just taken place, whereby Mendelian genetics was shown to be compatible both with the inheritance of continuous traits and with natural selection (Fisher 1930; Wright 1931; Haldane 1932; see Provine 2001). Dobzhansky and Mayr supported and extended the modern synthesis into the study of species and speciation (Mayr 1981, 1982; Smocovitis 1996). Dobzhansky's adoption of reproductive isolation and 'isolating mechanisms' (Dobzhansky 1935, 1937b) borrows heavily from entomologists (e.g. W. Peterson, A.P. Semenov-Tian'Shanskii) who had been actively debating 'physiological selection' (reproductive isolation) in Russia (Krementsov 1994). George Romanes (1886) in England had been the original proponent of physiological selection, whereby sterility was acquired via natural selection for a group benefit, species purity. As we have seen, Darwin's chapter Hybridism had argued that sterility was a mere by-product of evolution, rather than a key characteristic of species. Darwin had also largely convinced Wallace that adaptive intersterility was unlikely (Wallace 1886, 1889) since it was hard to imagine how it could arise under natural selection: individuals possessing the sterility trait would inevitably leave fewer offspring. Dobzhansky did not cite Darwin's ideas on hybridism or the controversy about physiological selection, and felt free to use 'physiological isolation' in defining species. Reproductive isolation seemed to him to make species more 'real' than mere varieties with gaps between them (Dobzhansky 1935, 1937a, b).

\section{Allopatric speciation}

Another influence on Russian, as well as on German evolutionary thought at this time was Moritz Wagner's 'Separationstheorie,' in which a small founder population must move to a geographically isolated location to provide an environment-triggered burst of variation leading to speciation (Wagner 1873, 1889). Wagner's ideas were later revived in a different guise, today called founder-effect speciation (Mayr 1954). The necessity, or not, of geographic isolation or allopatry, is intimately tied to one's view 
of species. Under the new reproductively cohesive view of species, geographic or reproductive isolation rather than natural selection was viewed as the key to speciation (Mayr 1942): “... the crucial process in speciation is not selection, which is always present in evolution even when there is no speciation, but isolation" (Mayr 1999: xix).

Darwin, as we have seen, had indeed considered geographic isolation in the origin of species, and thought it important, but viewed selection and his 'principle of divergence' as prime movers of speciation. By 1854 his barnacle study showed him that there was abundant variation in all organisms in a state of nature (Browne 1980). Darwin therefore needed no deus ex machina of changed conditions to provide variation. He altered the text of later editions of The Origin to refer to Wagner's work on geographic isolation, but the alteration had no effect on his general argument (Darwin 1872: 81). He was not in the least convinced by Wagner's "increasingly fanatical and scientifically naïve" dogma (Sulloway 1979), which argued that the initiation of evolutionary change required Lamarckian acquisition of variation after emigration to a new habitat (Wagner 1873, 1889). Finding his arguments exasperating, Darwin eventually wrote across the front page of a paper of Wagner's: "most wretched rubbish" (Sulloway 1979: 50). Darwin (1859) instead had, as we have seen, argued that repeated geographic isolation and contact within continents was a more important source of species that could survive competition than were small colonies on the peripheries of a distribution. The situation is analogous to a comparison between the 'shifting balance' idea of multiple population experimentation throughout the population range (Wright 1932), and Mayr's later founder effect, allopatric speciation involving migration and 'genetic revolutions' in peripheral populations (Mayr 1954).

Mayr (1942, 1963, 1982) repeatedly failed to appreciate Darwin's views on geographic isolation (see above), and held that Wagner's ideas were both fundamentally different from Darwin's, and also superior to them and closer to 'modern' views espoused by Mayr himself. Mayr also cited David Starr Jordan's work supporting Wagner on the purely geographical origins of new species (Jordan 1905a). In retelling the story of Wagner's ideas, Mayr seems to have studiously ignored the reasons for Darwin's rejection of Wagner's extreme views (Sulloway 1979), and he failed even to attend to important contemporary critiques of Wagner (Gulick 1891, 1908; Cook 1908), although they had convinced Jordan himself (Jordan 1905b). Because Mayr had a more cohesive view of species than Darwin, geographic isolation was virtually required for speciation: Darwin's argument for the primacy of natural selection in speciation then seemed incorrect.

\section{The discreteness of species}

Species were also now seen as more discrete than in Darwin's view. Dobzhansky originally came to the USA to work with the Drosophila geneticist Thomas Hunt Morgan. Morgan had earlier sided with the Mendelians William Bateson and Hugo de Vries, who supported mutation as the cause of new species, and argued that natural selection was inadequate to explain speciation (Morgan 1919). Bateson felt 
that species were sharply separated, especially via hybrid sterility and inviability, and that only saltational forms of evolution could therefore explain speciation (Bateson 1913, 1922). Here he argues strongly against the Darwinian view:

It had been decreed that when varieties of a species co-exist in nature, they must be connected by all intergradations, and it was an article of faith of almost equal validity that the intermediate form must be statistically the majority, and the extremes comparatively rare. ...

[But] An examination in the field of the interrelations of pairs of wellcharacterized but closely allied 'species' ... proved, almost wherever such an inquiry could be instituted, that [they could not] have been gradually evolved by natural selection ... (Bateson 1922: 56).

Bateson's earlier book (1913), to which Dobzhansky referred in 1935 was an impressive tour-de-force of biology and anatomy, showing considerable knowledge about the natural history of polymorphism. Bateson points out that discontinuous variation is found everywhere in nature, both between and within species (Bateson 1913). In my view, many of the intra-population discontinuities in hereditary variation described by Bateson are indeed Mendelian traits of large effect (though the genetic architecture may be more complex in some cases).

Bateson used this information to argue for saltational origins of species. Similar ideas were still popular much later (Schindewolf 1936; Goldschmidt 1940; see Bowler 1992). Dobzhansky, as is well known, denied the importance of saltation and supported gradualist speciation, but was convinced by Bateson and experimental genetics colleagues on an important point relevant here: that species are more discontinuous than Darwin had claimed, especially with regard to hybrid sterility. For this reason, Dobzhansky felt that a new species concept based on reproductive isolation was warranted:

In animal and plant groups which are taxonomically well understood, and excepting the so-called 'difficult' ones..., the delimitation of species usually is subject to no dispute at all (Dobzhansky 1951: 258).

... the relative rarity of borderline cases indicates that, although the process of divergence is a gradual one, the speciation in the strict sense, i.e., the development of reproductive isolation, is a crisis which is passed relatively rapidly (Dobzhansky 1951: 267).

The following quotation from Bateson (1913) is used as the header for Dobzhansky's 1935 paper, in his 1937 book, as well as much later in the 1951 edition of the same book, p. 259 (mis-attributed to Bateson 1922), to support his argument for fundamental discontinuities between species:

... though we cannot strictly define species, they have yet properties which varieties have not, and ... the distinction is not merely a matter of degree (Bateson 1913: 242).

A key aspect of this view of the discreteness of species is a very old one, tracing to Thomas Henry Huxley as well as Romanes (see Mallet 2008b), and then back to 
Buffon and the creationists: that distinct species are intersterile, and that Darwin had failed to explain this under natural selection. More nuanced arguments for positions similar to those of the mutationists on the discreteness of species and punctuated evolution appeared well into the 1940s (Schindewolf 1936; Goldschmidt 1940), and even later (Eldredge and Gould 1972). Darwin's clear argument in his chapter Hybridism, that species were just divergent varieties, and that sterility was variable and incidental to speciation was rejected or ignored by those who adopted this view (Conn 1888).

Hybrid inviability and sterility were particularly important to Dobzhansky, because he worked extensively on the mutually intersterile fruitflies Drosophila pseudoobscura and D. persimilis (Dobzhansky 1951). Earlier, these sibling species had been thought of as merely "races" of D. pseudoobscura (Dobzhansky $1937 \mathrm{a}, \mathrm{b})$. The idea that genes causing hybrid sterility and inviability are especially privileged "speciation genes," compared with other genes under natural selection, is still prevalent, even though they may not be involved with either initiation or completion of speciation (Orr et al. 2004; Mallet 2006). The important point here is, however, that 'physiological selection', especially hybrid sterility, was again seen as the trait that made the species boundary discrete and real.

While Dobzhansky was influenced by anti-Darwinian ideas on species emanating from physiological selection theory and mutationism, Mayr was receiving similar ideas from a different although related source in systematics. In the mid 1930s, Dobzhansky helped Mayr to fight off a bout of saltationism as well as Lamarckism (Mayr 1981; Haffer 2007: 133). Saltational speciation (Goldschmidt 1940) may have seemed attractive at this time as it fitted with the systematics training he had received in Berlin. Mayr had read the works of systematists such as Otto Kleinschmidt, Ernst Hartert, Walter Rothschild, Karl Jordan, Erwin Stresemann and Bernhard Rensch. Along with the American Ornithologist's Union and David Starr Jordan in the USA, these were among systematists arguing for versions of the polytypic species idea (Stresemann 1975; Mayr 1982; Rothschild 1983; Mallet 2004; Haffer 2007). The 'true' species themselves were now increasingly interpreted as distinct forms that could coexist in sympatry without intergradation, and the Darwinian idea that hybrids in contact zones were intermediates between species and varieties began to seem less likely.

Speciation became, so to speak, more difficult under this new view (Mallet 2008a), because the true sympatric species now seemed to be separated by 'bridgeless gaps' (Goldschmidt 1940). An early promoter of such ideas in Germany, Otto Kleinschmidt, was a minister in the Protestant church, and to him these revised polytypic species (Formenkreise) seemed so completely separated from one another that they provided evidence for separate creation (Mayr 1942: 113-114). To evolutionists like Rensch and Mayr, subspecies were again considered incipient species, as for Darwin. However, the smooth intergradation of geographic subspecies, contrasted with almost complete lack of intergradation of sympatric species, suggested that the new polytypic species were more distinct, and that 'doubtful species' would be rarer than Darwin had realized (see for example Mayr 1942: 148-149). 
Species as integrated, adaptive units, or 'superorganisms'

This emerging idea of species specialness was crystallized in the 1950s-1960s by Dobzhansky, Mayr and Alfred Emerson long before distinctions between group selection and individual, or gene-oriented selection had been clearly separated (Hamilton 1964; Williams 1966). 'Isolating mechanisms' were seen as adaptive traits that made species special, and were thought to be advantageous to the species as a whole. They prevented deleterious effects of gene flow on the 'adaptive gene complexes' that supposedly differed between species. Reproductive isolation between species seemed to mean that the species is the only 'real' category in the biological hierarchy, maintained as a homeostatic "supraindividual biological entity" (Dobzhansky 1951: 6). Dobzhansky did not change his views on this:

[The] species is not only a category of classification, but also a form of supraindividual biological integration. (Dobzhansky 1970: 358; see also pp.

23, 353-354)

Dobzhansky further developed a theory (Dobzhansky 1940), today called 'reinforcement' (Butlin 1995), whereby 'physiological isolating mechanisms' evolved to perfect reproductive isolation. Dobzhansky's terminology reflects nineteenth century ideas of physiological selection already mentioned (Romanes 1886; Wallace 1889). Dobzhansky as late as 1970 argued for the evolution of hybrid sterility and inviability, as well as mate choice, via reinforcement (Mallet 2010).

Mayr believed in the adaptedness of reproductive isolation, but paradoxically doubted the only possible mechanism, reinforcement (Mayr 1970: 325-327), perhaps because if it took place it would open the door to fully sympatric speciation. Today, theoretical, comparative and experimental evidence supports the existence of reinforcement acting on mate choice, but not hybrid sterility or inviability. Indeed, work with Drosophila suggests it or a similar process may commonly account for the evolution of assortative mating among sympatric species (Coyne and Orr 2004).

Although both Dobzhansky and Mayr clearly agreed with Darwin that hybrid inviability and sterility would often or primarily evolve as incidental by-products of divergent evolution, this did not prevent them from believing that reproductive isolation was an adaption to preserve species purity:

The reproductive isolation of a species is a protective device against the breaking up of its well-integrated, co-adapted gene system. Through organizing diversity into species, a system has been created that permits genetic diversification and the accumulation of favorable genes and gene combinations without any danger of destruction of the basic gene complex (Mayr 1963: 423).

It is the function of the isolating mechanisms to prevent such a breakdown and to protect the integrity of the genetic system of species. Any attribute of a species that would favour the production of inferior hybrids is selected against, since it results in a wastage of gametes. Such selection maintains the efficiency of the isolating mechanisms and may indeed help to perfect them. 
Isolating mechanisms are among the most important biological properties of species (Mayr 1970: 68)

Elaborate sexually dimorphic morphologies, as well as energetic courtship behaviours, were thus interpreted as traits that adaptively prevent hybridization. The possibility that such traits might instead be driven by Darwinian sexual selection or sexual conflict within species was dismissed:

... it is now realized that many phenomena that have been recorded in the past as furthering intraspecific sexual selection are actually specific recognition marks. Their primary function seems to be to facilitate the meeting and recognition of conspecific individuals and to prevent hybridization between different species (Mayr 1942: 254).

The term 'reproductive isolation' appears to originate with Alfred E. Emerson (1935). Emerson later became organiser of the short-lived and somewhat inactive Society for the Study of Speciation with Dobzhansky and Julian Huxley. Mayr tried to join this society and effect some activity, but was not permitted to do so (Cain 2000). Emerson was a strong supporter of the 'superorganism' concept in its application to social insects. Later, he became the key author on a comprehensive ecology textbook that extended the scope of the 'superorganism' idea not only to species, but also to whole ecological communities as units of integration (Allee et al. 1949). The pioneering British ecologist, Charles Elton, had long held similar views, arguing that population regulation evolved as an adaptation to avoid overpopulation (Elton 1927). It was apparently a lecture by Emerson on the superorganism theme that drove an exasperated G.C. Williams to write his wellknown critique of adaptation and natural selection, according to the 1996 preface in recent editions of his book (Williams 1966).

I hasten to add that these holistic, now unfashionable and anti-Darwinian ideas were not controversial from the 1940s to early 1960s. By 1963, Mayr clearly began to embrace sexual selection and argued (apparently without data or literature references) that male birds of paradise are selected for reproductive success, even potentially to the detriment of the species as a whole (Mayr 1963: 199), although he stopped short of suggesting a role for sexual selection in speciation. By 1970 both Mayr and Dobzhansky clearly understood the problems with group selection raised by W.D. Hamilton and G.C. Williams (Dobzhansky 1970: 425-428; Mayr 1970: 114-119). Yet this understanding somehow failed to dent their holistic views that reproductive isolating mechanisms were important species-level adaptations, as we have already seen (see also Mallet 2010).

The Mayr-Dobzhansky holistic view of species proved very successful. The idea was hailed by biologists as the great advance that enabled one to understand, for the first time, how speciation occurred. There were some critics, still well worth reading, of this new, more concrete view of species (Ehrlich and Raven 1969; Sokal and Crovello 1970), but detractors were in a minority. Here is an example of a gushing tribute to Mayr's way of thinking, in a popular book blending science and religion by the Oxford evolutionary biologist Alister Hardy: 
Hardly any one, until Ernst Mayr published his Systematics and the Origin of Species in 1942, really understood that the species was a unique unit, having quite a different significance in the evolutionary system from that of any other category. ... For a long time naturalists had accepted what had been called the practical species concept that Darwin held. ... We now realise that the species is something which is not just a matter of judgment but has a quite definite objective reality (Hardy 1965: 96).

Most books on evolution at the time said similar things, and the Mayr view was extremely seductive. The view that Darwin hadn't done his job properly was almost universal. To give another example, Michael Ghiselin wrote:

The biological species concept stresses the integrity of species as units of function. It emphasizes reproductive isolation because once a barrier to crossing has arisen, new units of interaction are formed, and for this reason the change from a geographic race to a species involves a fundamental alteration in the properties of the unit itself. ... Those who object to this differentiation should, to be consistent, affirm that there is no real difference between a foetus and a newborn infant, or between a living animal and a corpse. Darwin seems not to have fully appreciated the importance of the discontinuity ... (Ghiselin 1969: 101).

It is therefore advantageous to organisms that they are broken up into separate populations, for these can each be modified and adapted to a particular way of life (Ghiselin 1969: 146-147).

Oddly, Ghiselin had earlier in this same volume performed a careful analysis demonstrating Mayr's misrepresentation of many aspects of Darwin's view of species (Ghiselin 1969: 89-101). Nonetheless Ghiselin here agreed with Mayr that Darwin did not understand the adaptive and integrated nature of species, and therefore had been unable to make much headway on speciation. Ghiselin instead viewed species to be analogous, in logic, to individual organisms: homeostatic wholes, real 'units' with defined births, deaths and lifetimes. Species were no longer nominalistic classes of organisms settled merely by agreement between good systematists, as Darwin had suggested, they were in a sense "real individuals" (Ghiselin 1969: 53; Ghiselin 1974).

Today, the full force of the sociobiological revolution has swept through biology. Altruism in the biological sense evolves normally only if it benefits an individual's kin, or its own 'selfish genes.' It is now almost a null hypothesis that group selection does not occur. Darwinian sexual selection has been rehabilitated (Andersson 1994). The group selectionism of the biological species concept of the 1950s-1970s, and of Ghiselin's 'species as individuals' idea, has been highlighted a number of times (Kitcher 1984; Paterson 1985; Ruse 1987; Williams 1992; Mallet 2010).

One hundred and fifty years after The Origin, almost no space is today devoted to species as stable, cohesive units maintained by group-advantageous 'mechanisms.' Instead, we instead discuss the roles of sexual selection and sexual conflict on speciation extensively (Rice 1998; Coyne and Orr 2004; Ritchie 2007; Price 2008). What has been termed selection for species recognition or 'specific mate recognition 
systems' (Paterson 1985) can be seen to occur either via coevolution of mating preferences with traits of individual mates, or via reinforcement between species (Coyne and Orr 2004: 220). The first process, coevolution of preference with new recognition traits as they evolve, is simply a form of 'good-genes' sexual selection (Andersson and Simmons 2006): individuals preferring to mate with disfavoured ancestral phenotypes will be weeded out. The second process, reinforcement, or avoidance of matings with individuals when hybridization is deleterious, can also be considered a form of sexual selection for 'good genotypes' in offspring, rather than a species-level trait at all (see also Coyne and Orr 2004: 221; Ritchie 2007; Mallet 2010). Darwinian sexual selection acts on individuals, and so can divide species as readily as hold them together (Ritchie 2007). Therefore, an argument can now be made that the term 'species recognition' itself is devoid of meaning. The Darwinian view of the primacy of natural and sexual selection has largely supplanted grouprelated ideas of reproductive isolating mechanisms and species recognition.

Genetic markers and population genetics

Another important reason why Darwin's view of species was rejected in the postWorld War II period seems to have been purely practical. Before the Watson-Crick model of DNA, the nature of Mendelian genes and how they acted was hard to imagine. Even as late as 1951, Dobzhansky (1951: 13-14) doubted the emerging 'one-gene-one-enzyme' hypothesis. Such a simple biochemical function of the gene did not seem enough for geneticists at that time. One of the ground-breaking molecular biologists of that generation, Jacques Monod, put it well: "The gene was, in the minds of people, ... as inaccessible, by definition, as the material of the galaxies" (Monod in Judson 1996: 403). Monod was discussing the situation in 1958. Abundant genetic markers applicable to natural populations first became available only in the late 1960s and 1970s (Avise 2000). Before the mid 1960s it would have been almost impossible to detect Darwinian gaps in distributions of genotypes.

In this climate, the problem of identifying cryptic taxa led to the view that downstream effects of genes such as morphology were unsuitable for characterising species. Morphologically similar, although biologically divergent, sibling species, were well known, even to Darwin (e.g. the 'willow wrens,' Phylloscopus) (Darwin 1863), as well as to Dobzhansky (e.g. Sturtevant's discovery of Drosophila persimilis as an 'intersterile race' of D. pseudoobscura) (Dobzhansky 1937a). For Dobzhansky and Mayr, this militated against a Darwinian definition based on gaps in morphology or other direct products of heredity. The opposite problem, of separate sexes or single locus polymorphs separated by large morphological gaps, such as Batesian mimicry polymorphisms in Papilio (Poulton 1904), added fuel to the argument that mere genotypic or phenotypic data could not be used to detect species.

With gene action still a mystery, what was thought to be required was a more allencompassing, 'biological' concept of species. The solution seemed to be to define species via species-level functional traits that maintain separateness-reproductive isolation, rather than via the separateness of the morphological or genotypic 
distributions itself (Poulton 1904; Jordan 1905c; Dobzhansky 1935, 1937b; Mayr 1942). With molecular markers, this particular problem has vanished. Darwinian peaks and gaps in the frequency distribution of multilocus genotypes can now be detected readily, even in cryptic and sibling species (Avise 2000), and newer statistical analyses allow multilocus genotypes to be assigned to species (Pritchard et al. 2000). Today, these tools allow us to make inferences about reproductive isolation from Darwinian clusters revealed by multilocus population data. We no longer need, as Dobzhansky and Mayr believed, to infer species clusterhood on the basis of mating behaviour and hybrid viability (although it can be used as evidence).

Influence of the new biological view of species on understanding Darwin

Having convinced himself of the superiority of the biological species concept, Mayr, the major promoter of the new biological species concept, made a series of important historical analyses of Darwin's writings on species (Mayr 1959, 1963, 1982). The difficulty with Mayr's interpretation is that beliefs about species can interfere with an understanding of Darwin on his own terms. Mayr has been accused of this a number of times (Ghiselin 1969, 2004b; Kottler 1978; Sulloway 1979; Mallet 2008b). Mayr repeatedly used in these analyses highly abbreviated quotations, copied from in longhand The Origin on notecards, which must have exacerbated the difficulty of interpreting Darwin (Appendix, Ghiselin 2004b). Mayr's (1982: 267) Origin quotations are perhaps the fullest Mayr has given in support of his contention that Darwin misunderstood the nature of species. In some cases, Mayr's selected quotations appear to make Darwin say almost the opposite of what was meant by the original passages from which they are taken. In the Appendix I detail how these abbreviated quotations can misrepresent Darwin's views. It seems important here to highlight how Mayr quoted Darwin because many biologists, as well as philosophers and historians of science still repeatedly re-use these same quotations from The Origin.

In conclusion, dissatisfaction with Darwinian ideas about species stemmed from a number of beliefs held by biologists of the mid-twentieth century. First, there arose a dogma that reproductive isolation between species made them more real than Darwin had realized they were, and it was argued that Darwin did not understand the importance of intercrossing in preventing divergence. (However, Darwin certainly did understand both hybrid sterility and assortative mating, although rejecting their importance in defining species.) Related to the problem of reproductive isolation, a second belief was that Darwin did not appreciate the role of geography in preventing gene flow, and in allowing divergence leading to speciation (again, he had a good understanding of geographic isolation). Third, species were thought more distinct from one another than Darwin had reputedly said they were (I argue here that Darwin's views were again, however, misinterpreted). This claim was emphasized particularly by Bateson and other mutationists, but later taken up by Dobzhansky and the 'new systematists' who doubted the efficacy of natural selection alone to produce the 'bridgeless gaps' they thought they saw between species. Fourth, biologists were prone to adopt a group selectionist view that species were endowed with homeostatic internal mechanisms for their preservation, 
'reproductive isolating mechanisms,' 'cohesion mechanisms,' or 'specific mate recognition systems' (all are now generally disbelieved). Finally, Darwin's character-based view of species as evidenced by gaps in variation seemed impossible to apply to compatible but morphologically divergent morphs within species, or to morphologically similar but reproductively isolated 'sibling species.' Reproductive isolation therefore seemed a better definition of species. (However, abundant molecular markers and better statistical treatment of multilocus genetic data now allows species delimitation using a Darwinian cluster criterion.) Finally, these twentieth century biological beliefs about species, coupled with overabbreviated quotations from Darwin, led to a misrepresentation of Darwin's views, making rejection of them easier.

\section{Conclusions}

I have documented here Darwin's understanding of reproductive isolation, the nature of species, the importance of intercrossing in preventing divergence, and geographic isolation, the whole of which he has been accused of lacking, especially by Mayr. It can perhaps be argued that Darwin didn't have the 'right' species concept, but this argument loses its force today, since Mayr's biological species concept is no longer accepted as the gold standard. Many other conflicting concepts of species are now debated.

Another argument repeatedly stressed is that Darwin "never seriously attempted a rigorous analysis of the problem of the multiplication of species, of the splitting of one species into two" (Mayr 1963: 12). See also Coyne and Orr (2004: 11): “for Darwin, the origin of species was identical to the origin of adaptations within species - the production of different varieties. He therefore conflated the problem of change within a lineage with the problem of the origin of new lineages". While Darwin did think that natural selection would explain both processes, it seems to me quite odd that anyone, after reading The Origin, can seriously contend he didn't understand the need to explain divergence. Indeed, he proposed his 'principle of divergence' and 'principle of extinction' for this very purpose (Browne 1980; Mallet 2008b; Kohn 2009). One might argue that Darwin's model for species splitting was wrong (Mayr 1992b; Coyne and Orr 2004), but this is very different from claiming he hadn't realized the problem existed. In any case, Darwin's principle of divergence is not far from today's respected theories for ecological speciation and adaptive radiation (Rundle and Nosil 2005; Gavrilets and Losos 2009; Schluter 2009; Reznick and Ricklefs 2009).

An important criticism that can perhaps be leveled at Darwin is that he didn't express himself in The Origin as clearly as he might have done. In retrospect, Darwin could have clarified matters for his distracted future readership in the twenty first century, bombarded as we are by a massive electronic and print media. In Chapter II of his first edition, he could have clearly distinguished geographic from non-geographic varieties (as did Wallace 1865, for example, as well as Jordan $1905 \mathrm{c}$, much later). He could have outlined the influences of genealogy, mate preference, and hybrid sterility on the gaps between species. It is also perhaps 
unfortunate that he did not include an entry on 'species' in a glossary of technical terms (a suitable glossary was added by the 6th edition of 1872, but 'species' was still not in it-too obvious, perhaps?).

The result of the lack of an overt species definition means one can think of exceptions, in which 'good' species are not covered by Darwin's 'gap' argument, and Mayr takes Darwin to task for this. But species are difficult to define. When dealing with similar exceptions to his own, 'biological' species concept, Mayr (1963: 22) thunders: "Do we abandon these categories because there are borderline cases and transitions? Do we abandon the concept tree because there are dwarf willows, giant cactuses, and strangler figs?" In retrospect, it is unfortunate that Mayr did not think to apply his tolerance of exceptions to Darwin's view of species as well.

There is one way to justify Mayr's argument that species are a bit more real than any other taxonomic category. This is the existence of multi-character gaps when in contact, or sympatry. It was sympatry which Darwin didn't clarify adequately; this was left to Wallace (1865), and later Poulton (1904) who coined the term 'sympatry' (Mallet 2004, 2008b; Mallet et al. 2009). Gaps also exist between sympatric polymorphic phenotypes (or genotypes) within species, but they are not correlated with other polymorphisms. It is thus correlation among unrelated characters in sympatry that we intuitively use to recognize quantitative gaps between separate species. We use similar gaps to separate organisms into higher taxa, such as animals and plants, butterflies and moths, or lizards and birds, or lower taxa, such as subspecies and races. Some of these may not be 'real' monophyletic taxa, but we do somehow conceive of these as useful groups as well. But species represent perhaps the lowest level in the hierarchy of multilocus genetic correlations in sympatry; and this is really what the Dobzhansky-Mayr non-dimensional, reproductive isolation definition attempted to capture. Darwin was aware of sympatry and allopatry, and indeed clearly defined species at approximately the same taxonomic level in sympatry ("within the same area", and "in a wellinvestigated region") as the rest of us in The Descent of Man (Darwin 1871: 215). He was certainly not as clear about it in The Origin as he might have been, perhaps because his argument became over-abbreviated in the mere 'abstract' of the 'big book' that The Origin was intended to be (Stauffer 1975; Sulloway 1979; Beatty 1985; Sloan 2009).

Darwin put together the first comprehensive argument for evolution of species. Some lack of clarity can surely, now, be tolerated without automatically concluding that Darwin failed or was wrong. Evolutionary biologists are again becoming more Darwinian in their outlook on speciation and evolution in general than they have been for around 120 years (Mallet 2001; Orr 2009; Schluter 2009). Considering Darwin's ignorance of Mendelian genetics, it is uncanny just how much he got right about species.

Acknowledgments This article was written while the author was in receipt of generous sabbatical fellowships at the Wissenschaftskolleg zu Berlin and the Radcliffe Institute at Harvard University. I am extremely grateful to Janet Browne, Marc Ereshefsky, Sheila Fitzpatrick, Jürgen Haffer, Michael Ruse and two anonymous reviewers for critically reading the manuscript, and to the library staff of the Wissenschaftskolleg for help in tracing many original sources. I am especially grateful to Maureen 
O'Malley for heroic editorial work, which has greatly benefited this final version. I am also grateful to Axel Meyer, Patrik Nosil, and Jeff Feder, all fellow members of the Schwerpunktgruppe on Sympatric Speciation at the Wissenschaftskolleg, and Richard Lewontin for discussions and support. This paper was first presented at the workshop, Perspectives on the Tree of Life, sponsored by the Leverhulme Trust and held in Halifax, Nova Scotia, July, 2009.

\section{Appendix: How was Darwin's text misread?}

The scientific, and possibly political and metaphysical climate of the times forms the background against which a new understanding of species arose in the 1930s and 1940s. However, this does not excuse misreading Darwin, and I here argue the most influential proponent of the new, non-Darwinian view of species did just this. The claim was made that a revolution against Darwin's species concept, rather than a modification or improvement of it, was required. Here I show that extremely abbreviated extracts from The Origin exacerbated still further a view of Darwin's understanding of species promulgated by Mayr in particular. There is a danger, of course, in turning the reading of Darwin into a kind of hermeneutics. However, I believe the case against Darwin's failure to define species is so clear, once one understands his actual views, that it seems a pity not to highlight how easily Mayr's extracts can be misleading, especially as this evidence is apparently unknown to many historians of science, even by those generally critical of Mayr's analysis of Darwin.

Evolutionary biologists probably rarely read Darwin today, with some enlightened exceptions (Berry and Hoekstra 2009). When they do, they tend to skim the "turgid Victorian prose that is uncongenial to modern readers" (Coyne 2008). Even after re-reading The Origin, presumably repeatedly, biologists continue to argue that "speciation ... was terra incognita for Darwin" (Berry and Hoekstra 2009), or that "his views on species and speciation are pretty wonky" (Coyne 2009). In the 1900s-1950s, the climate for understanding Darwin was far worse than today. Darwinism had been in decline (Bowler 1992), and though Darwin was revered as the initiator of evolutionary thought, a 'modern' book on evolution or systematics probably didn't require careful reading of Darwin. References by Dobzhansky (1937b) and Mayr (1942) to Darwin or history are generally cursory at this stage (Winsor 2006).

With the centenary of The Origin, it is clear that Mayr in particular did begin to read Darwin's text carefully (Mayr 1959, 1963); indeed he edited the facsimile reprint of the first edition of The Origin I have used here (Mayr 1964). Mayr's later work includes abundant quotations from Darwin. Yet his assessment of Darwin's view of species remained entirely negative, largely perhaps because everything Darwin said on species seemed so strongly opposed to Mayr's own 'correct' and 'modern,' reproductive isolation definition of species. Mayr, of course, was not the only influence on evolutionary thought at the time. Yet it is curious that many philosophers and historians of science and biologists use the same quotations about species from The Origin, exactly as cited by Mayr (these co-citations are highlighted below). This is probably because, even when critical of Mayr's analysis of Darwin, these authors often side with Mayr's instead of Darwin's view of species. 
My evidence here consists of seven quotations used by Mayr to support his argument on 'Darwin's failure' in The Growth of Biological Thought (Mayr 1982: 267). These make up perhaps the most complete statement anywhere of the modern case against Darwin's view of species. According to Mayr, these quotations show how Darwin had changed his mind about the definition of species from an emphasis on reproductive isolation in his notebooks to a kind of nihilism in The Origin. Darwin was apparently at this time “... increasingly influenced by the botanical literature and by correspondence with his botanical friends" (Mayr 1982: 267; Sulloway 1979), although why Mayr felt that plant species should be any less wellformed than animal species is not clear (Knapp 2008).

However, Mayr's interpretation of Darwin's views in The Origin is now generally viewed as erroneous (Ghiselin 1969). As Ghiselin has remarked:

Mayr [had the] notion that Darwin was inconsistent about species concepts, which I had corrected ... earlier [Ghiselin 1969]. As I explained in a passage that was suppressed by the editor of the journal, Mayr reached his conclusion by writing out what Darwin said on cards, and deciding that the statements on the cards were inconsistent (Ghiselin 2004a).

Many problems Mayr (1982: 267) had in interpreting Darwin indeed stemmed from his use of extremely abbreviated quotations. Here I go through the quotations to show how they could have been misconstrued. The first is:

(1) "No one definition has as yet satisfied all naturalists; yet every naturalist knows vaguely what he means when he speaks of a species." (Darwin 1859: 44, 1872: 33).

Here Darwin merely highlights an existing controversy about what are 'real' species. The quotation does not at all show that Darwin himself denied that species exist. The very next paragraph, overleaf, shows what he means here; "Generally the term includes the unknown element of a distinct act of creation." In other words, Darwin is saying simply that many naturalists and scientists of his day were special creationists, but even so they can't agree where to draw the line. This statement can hardly be viewed as controversial today, and it does not provide any evidence that Darwin's species concept had changed or was inadequate.

The next, very widely cited quotation comes much closer to today's perceived view of Darwin's failure to define species scientifically:

(2) "In determining whether a form should be ranked as a species or a variety, the opinion of naturalists having sound judgment and wide experience seems the only guide to follow." (Darwin 1859: 47, 1872: 37 . Also used by Mayr 1942: 115; Ghiselin 1969: 95; Wright 1978: 1; McOuat 1996: 515; Ereshefsky 2009: 5-6!, and many others).

Tellingly, a key word, "Hence," has been omitted by Mayr from the beginning of Darwin's own sentence, in 1942 as well as in 1982. The "Hence, in determining ..." is necessary in Darwin's text because this sentence forms the conclusion to an argument that varieties are similar to species in difficult cases. 
The header on these pages is "DOUBTFUL SPECIES." Above the quotation, on the same page, Darwin (1859) argues: "Practically, when a naturalist can unite two forms together by others having intermediate characters, he treats the one as a variety of the other, ranking the most common, but sometimes the one first described, as the species, and the other as the variety." Here we have Darwin's clear, if somewhat implicit criterion for species defined by gaps in variation; varieties, on the other hand, lack gaps. But Darwin then cites some problems: “... cases of great difficulty ... sometimes occur in deciding whether or not to rank one form as a variety of another, even when they are closely connected by intermediate links..." (Darwin 1859: 47). Doubtful cases exist, "Hence, ... the opinion of naturalists ... seems the only guide to follow."

This fuller and more correct reading of Darwin's is reinforced by the very next sentence, overleaf, also under the heading "DOUBTFUL SPECIES." It begins: "That varieties of this doubtful nature are far from uncommon cannot be disputed ..." (Darwin 1859: 48, my emphasis). Darwin is not at all saying, as might be supposed from the partial quotation used by Mayr, as well as many others, that all species are arbitrary units to be determined only via agreement of specialists. He is saying only that the most difficult cases must be so judged, since these borderline cases are indeed a matter of opinion. This is as true today as it was in Darwin's time.

Now it becomes easier also to understand the following two quotations also from the same section of The Origin:

(3) "From these remarks, it will be seen that I look at the term species as one arbitrarily given for the sake of convenience to a set of individuals closely resembling each other, and that it does not essentially differ from the term variety, which is given to less distinct and more fluctuating forms." (Darwin 1859: 52, 1872: 42; see also p. 469. Also used in Mayr 1959: 222, 1963: 14; Ghiselin 1969: 93, 95; Kottler 1978: 292, 294; Coyne and Orr 2004: 10; Ereshefsky 2009: 4!).

An earlier statement spanning p. 51 (headed "DOUBTFUL SPECIES," as before) to p. 52 (headed "VARIETIES GRADUATE INTO SPECIES") reads: "And I look on varieties which are in any degree more distinct and permanent, as steps leading to more strongly marked and more permanent varieties; and at these latter, as leading to sub-species, and to species." Again, we have the clear assertion of the importance of species distinctness, and that varieties are not distinct. Species are certainly on the same continuum as varieties, but the "arbitrary" criterion we use is that species are more distinct: they have gaps between them. Then, four pages later we have the fourth quotation used by Mayr:

(4) "Hence the amount of difference is one very important criterion in settling whether two forms should be ranked as species or varieties." (Darwin 1859: 56-57, 1872: 45; also used in Mayr 1959: 222. Similar statement in The Origin p. 485 cited by Ghiselin 1969: 98).

On p. 48, Darwin had been arguing that the number of plant species in Britain is disputed among naturalists because the criterion of gaps in the distribution of forms can fail. In contrast, "amongst animals which unite for each birth, and which are 
highly locomotive, doubtful forms ... can rarely be found in the same country, but are common in separated areas." In sympatry, animal species are normally identifiable via gaps, but the problem of making a decision about geographically separated plant or animal populations constantly besets taxonomists, no less today than in Darwin's time.

In spite of his criticism of Darwin, Mayr recognized the same problem. He argued for "the importance of a nonarbitrary definition of species" (Mayr 1963: 29), but he also recognized that "one finds many populations in nature that have progressed only part of the way towards species status. They may have acquired some of the attributes of distinct species and lack others. One or other of the three most characteristic properties of species-reproductive isolation, ecological difference, and morphological distinguishability-is in such cases only incompletely developed" (Mayr 1963: 24). "The decision whether or not to call such populations species is by necessity somewhat arbitrary" (Mayr 1982: 282).

As did Darwin, Mayr argued that the 'problem' was particularly severe in geographically separated populations: "Even though the number of cases causing real difficulties to the taxonomist is very small, it cannot be denied that an objective delimitation of species in a multidimensional system is an impossibility" (Mayr 1963: 24). By 'multidimensional system' Mayr meant one consisting of multiple spatially or temporally separated populations showing various levels of genetic divergence. "To determine whether or not an incipient species has reached the point of irreversibility is often impossible" (Mayr 1963: 26).

So what did Mayr think of such doubtful forms? Should they be classified as subspecies, or as separate species? “...Isolated forms, or 'insular species,' are excellent evidence in support of geographic speciation and, as such, welcome to the student of evolution; but, on the other hand, they are also very troublesome to the modern taxonomist" (Mayr 1942: 166). Ideally, one would like to infer whether, if brought back together, these populations would remain distinct. "...It is necessary in the cases of interrupted distribution to leave it to the judgment of the individual systematist, whether or not he considers two particular forms as 'potentially capable' of inbreeding - in other words, whether he considers them subspecies or species. ... We may have to apply the degree of morphological difference as a yardstick in all those cases in which we cannot determine the presence of reproductive isolation" (Mayr 1942: 120-121).

Mayr, like Darwin, evidently felt that the degree of morphological difference was useful in doubtful cases, based on the taxonomist's knowledge of the group. Comparing this to the degree of difference normally shown by good species in sympatry in the same group would enable decisions about the taxonomic status of isolated populations. Note that Mayr uses almost the exact same wording as Darwin about degree of morphological differences, the need for taxonomists' (or naturalists') judgment, and the 'somewhat arbitrary' nature of the decision. The main difference is that Darwin concluded from this that species, at least in difficult cases, were somewhat arbitrary, whereas Mayr, although agreeing with this conclusion in practice for species taxa, was somehow still able to conceive of his own theoretical species concept as non-arbitrary. The view of species implied in Mayr's writings is, in practical terms, therefore only hair-splittingly different from 
that in Darwin's. It seems particularly underhand for Mayr to argue that Darwin had an incomplete understanding of species on the basis of the same arguments and indeed almost the same words that Mayr himself uses about the fuzziness of borderlines between doubtful species.

The next quotation used by Mayr is probably the most egregiously tendentious abridgment of the whole crop:

(5) "Varieties have the same general characters as species, for they cannot be distinguished from species." (Darwin 1859: 58)

The complete sentence from which this apparently nonsensical statement is extracted reads (NOTE: [] = omissions, bold text = additions, in Darwin 1872: 47):

Finally [, then,] varieties [have the same general characters as species, for they] cannot be distinguished from species, - except, first[ly], by the discovery of intermediate linking forms[, and the occurrence of such links cannot affect the actual characters of the forms which they connect]; and [except,] secondly, by a certain indefinite amount of difference between them [, for two forms, if differing very little, are generally ranked as varieties, notwithstanding that intermediate linking forms have not been discovered]; but the amount of difference considered necessary to give to two forms the rank of species is quite indefinite (Darwin 1859: 58-59, Darwin 1872: 47).

This represents the beginning of a two-page conclusion to Chapter II, on "Variation under Nature." Darwin has been continuing to document how systematists differ in assigning taxa as species or varieties, thus providing further evidence for transmutation of varieties into good species with gaps between them. Darwin points out some other interesting patterns also relevant to transmutationist ideas, for instance that varieties have more restricted distributions than good species, and that species in larger genera (i.e. with more species) tend to be more similar (i.e. more like varieties) than species in smaller genera, as might be expected if rampant evolution of varieties continued into similar diversification of species (Browne 1980). The four pages 56-59 are headed SPECIES OF LARGE GENERARESEMBLE VARIETIES.

The major misunderstanding perpetrated by Mayr's abridgment is the omission of Darwin's first exception; the resultant abbreviated quotation then seems to mean almost the exact opposite of what Darwin intended. Darwin is clearly saying, here, that varieties do differ from species by "the discovery of intermediate linking forms...." The "- except, firstly..." section must be read to avoid making a nonsense out of what Darwin is attempting to say! The second exception is of course again Darwin's argument for use of "degree of difference" in doubtful cases (as did Mayr). Interestingly, another commentator has used a different extreme abbreviation of the above sentence, "... the amount of difference considered necessary to give to two forms the rank of species is quite indefinite" (Kottler 1978: 291) as similar evidence for Darwin's apparent nihilism. I think it is quite clear what Darwin intended throughout this chapter, and in this concluding sentence as well. $\mathrm{He}$ was discussing the difficulty of actual taxonomic decisions in doubtful intermediate cases. He did not base his whole concept of species on an arbitrary 
degree of difference. His species were instead varieties that had evolved gaps in morphology.

A different kind of misreading is often done with Darwin's chapter VIII, Hybridism, as I have previously argued (Mallet 2008b). Here is the next quotation used by Mayr (1982: 267):

(6) "It can thus be shown that neither sterility nor fertility affords any [clear] certain distinction between species and varieties" (Darwin 1859: 248, Darwin 1872: 237. Also used by Hull 1967: 336)

Darwin is actually arguing here against the prevailing view, most notably from Buffon, for special creation of species on the grounds of unbridgeable gap of sterility. However, he starts by seeming to state the converse:

"The fertility of varieties, that is of the forms known or believed to have descended from common parents, when intercrossed, and likewise the fertility of their mongrel offspring, is, on my theory, of equal importance with the sterility of species; for it seems to make a broad and clear distinction between varieties and species" Darwin 1859: 246).

It seems to make a clear distinction, and Darwin agrees there is a good correlation between hybrid sterility or inviability and species status. But, he continues, there are cases of sterility within species, and cases of fertility between species. Because of our knowledge of similar cases of mismatch, evolutionary biologists today agree with Darwin that sterility and inviability does not make an absolutely clear distinction between species (Gourbière and Mallet 2010). Darwin is not at all arguing that that reproductive isolation of species is unimportant, but instead that the lack of a precise correlation with reproductive isolation merely demonstrates the evolutionary continuity of sterility among species and varieties (Kottler 1978).

The final quotation used by Mayr is from Chapter XIV, the Recapitulation and Conclusion of The Origin:

(7) "In short, we shall have to treat species in the same manner as those naturalists treat genera, who admit that genera are merely artificial combinations made for convenience" (Darwin 1859: 485. Also used by Hull 1967: 336; Ghiselin 1969: 91, Dobzhansky 1970: 352; Kottler 1978: 292; Coyne and Orr 2004: 10; McOuat 1996: 474; Ereshefsky 2009: 4!)

Once again we come back, in the summary of the whole book, to problems already dealt with about Chapter II (Mayr's Darwin quotations 1-5, above). Mayr again ignores Darwin's statements on species in the earlier chapter. Mayr even ignores what Darwin said clearly about species further up on this same page 485 (already cited in the section on Darwin's view of species): “... varieties ... are known, or believed, to be connected at the present day by intermediate gradations, whereas species were formerly thus connected." Quoted out of context, Mayr's abridgement appears to attribute to Darwin an utterly vacuous view of species. But the argument of Chapter II, summarised further up on p. 485, is that species are distinct from varieties by having gaps in variation between them, although intermediates are common, and it is difficult to make the actual distinction at the boundary between 
species and varieties in such doubtful cases. Hence, species are as difficult to define as genera for exactly the same reasons of evolutionary continuity. Darwin stressed it like this because, as before, he was trying to persuade the reader that species evolved from varieties, and that genera evolved from species in the same way (Ghiselin 1969; Kottler 1978; Beatty 1985; Stamos 2006). The argument makes as much sense today as it did to Darwin.

Taken in context, therefore, these abridged quotations fail to prove Mayr's thesis. They show neither that Darwin believed all species were continuous with one another, nor that Darwin significantly changed his mind about what species were in the years leading up to The Origin (see also Ghiselin 1969; Sulloway 1979).

\section{References}

Allee WC, Emerson AE, Park O, Park T, Schmidt KP (1949) Principles of animal ecology. W.B. Saunders, Philadelphia

Andersson M (1994) Sexual selection. Princeton Univ Press, Princeton

Andersson M, Simmons LW (2006) Sexual selection and mate choice. Trends Ecol Evol 21:296-302

Arnold ML (2006) Evolution through genetic exchange. Oxford University Press, Oxford

Avise JC (2000) Phylogeography. Harvard University Press, Boston

Bailey LH (1896) The philosophy of species-making. Bot Gaz 22:454-462

Bates HW (1862) Contributions to an insect fauna of the Amazon valley. Lepidoptera: Heliconidae. Trans Linn Soc Lond 23:495-566

Bateson W (1909) Heredity and variation in modern lights. In: Seward AC (ed) Darwin and modern science. Essays in commemoration of the centenary of the birth of Charles Darwin and of the fiftieth anniversary of the publication of The Origin of Species. Cambridge University Press, Cambridge, pp $85-101$

Bateson W (1913) Problems of genetics. Yale University Press, New Haven

Bateson W (1922) Evolutionary faith and modern doubts. Science 55:55-61

Beatty J (1985) Speaking of species: Darwin's strategy. In: Kohn D (ed) The Darwinian heritage. Princeton University Press, Princeton, pp 265-281

Berlocher SH, Feder JL (2002) Sympatric speciation in phytophagous insects: moving beyond controversy? Ann Rev Entomol 47:773-815

Berry A, Hoekstra HE (2009) Teaching the origin. Curr Biol 19:R9

Bock WJ (1995) The species concept versus the species taxon: their roles in biodiversity analyses and conservation. In: Arai R, Kato M, Doi Y (eds) Biodiversity and evolution. National Science Museum Foundation, Tokyo, pp 47-72

Bowler PJ (1989) The Mendelian revolution. The emergence of hereditarian concepts in modern science and society. Athlone Press, London

Bowler PJ (1992) The eclipse of Darwinism, 2nd edn. Johns Hopkins University Press, Baltimore

Bowler PJ (2003) Evolution. The history of an idea, 3rd edn. University of California Press, Berkeley

Bowler PJ (2009) Geographical distribution in the Origin of Species. In: Ruse M, Richards RJ (eds) The Cambridge companion to the "Origin of Species". Cambridge University Press, Cambridge, pp $153-172$

Britton NL (1908) The taxonomic aspect of the species question. Am Nat 42:225-242

Browne J (1980) Darwin's botanical arithmetic and the "principle of divergence", 1854-1858. J Hist Biol 13:53-89

Butlin RK (1995) Reinforcement: an idea evolving. Trends Ecol Evol 10:432-434

Cain J (2000) Towards a 'greater degree of integration:' the society for the study of speciation, 1939-41. Br J Hist Sci 33:85-108

Conn HW (1888) The significance of 'variety' and 'species'. Science 11:253-254

Cook OF (1908) Evolution without isolation. Am Nat 42:727-731 
Coyne J (2008) Which science book should the next US president read? The blind watchmaker by Richard Dawkins. Nature 455:464-465

Coyne JA (2009) (Re)reading The Origin. Curr Biol 19:R1

Coyne JA, Orr HA (2004) Speciation. Sinauer Associates, Sunderland

Darwin CR (1859) On the Origin of Species by means of natural selection, or the preservation of favoured races in the struggle for life. John Murray, London

Darwin CR (1863) [Review of] Contributions to an insect fauna of the Amazon Valley. By Henry Walter Bates, Esq. Transact. Linnean Soc. Vol. XXIII. 1862, p. 495. Nat Hist Rev 3:219-224

Darwin CR (1871) The descent of man, and selection in relation to sex. John Murray, London

Darwin CR (1872) The Origin of Species by means of natural selection, or the preservation of favoured races in the struggle for life, 6th edn. John Murray, London

de Queiroz K (1998) The general lineage concept of species, species criteria, and the process of speciation. A conceptual unification and terminological recommendations. In: Howard DJ (ed) Endless forms. Species and speciation. Oxford University Press, New York, pp 57-75

de Vries H (1909) Variation. In: Seward AC (ed) Darwin and modern science. Essays in commemoration of the centenary of the birth of Charles Darwin and of the fiftieth anniversary of the publication of The Origin of Species. Cambridge University Press, Cambridge, pp 66-84

Dobzhansky T (1935) A critique of the species concept in biology. Philos Sci 2:344-355

Dobzhansky T (1937a) Genetic nature of species differences. Am Nat 71:404-420

Dobzhansky T (1937b) Genetics and the Origin of Species. Columbia University Press, New York

Dobzhansky T (1940) Speciation as a stage in evolutionary divergence. Am Nat 74:312-321

Dobzhansky T (1951) Genetics and the Origin of Species, 3rd edn. Columbia University Press, New York

Dobzhansky T (1970) Genetics of the evolutionary process. Columbia University Press, New York

Drès M, Mallet J (2002) Host races in plant-feeding insects and their importance in sympatric speciation. Philos Trans R Soc Lond B 357:471-492

Dupré J (1981) Natural kinds and biological taxa. Philos Rev 90:66-90

Dupré J (1999) On the impossibility of a monistic account of species. In: Wilson RA (ed) Species: new interdisciplinary essays. MIT Press, Cambridge, pp 3-22

Ehrlich PR, Raven PH (1969) Differentiation of populations. Science 165:1228-1232

Eldredge N, Gould SJ (1972) Punctuated equilibria: an alternative to phyletic gradualism. In: Schopf TJM (ed) Models in paleobiology. Freeman Cooper, San Francisco, pp 82-115

Elton CS (1927) Animal ecology, new impression with additional notes, 1935 edn. Sidgwick \& Jackson, London

Emerson AE (1935) Termitophile distribution and quantitative characters of physiological speciation in British Guiana termites (Isoptera). Ann Entomol Soc Am 28:369-395

Endersby J (2008) Imperial nature: Joseph Hooker and the practices of Victorian science. University of Chicago Press, Chicago

Ereshefsky M (1991) Species, higher taxa, and the units of evolution. Philos Sci 58:84-101

Ereshefsky M (2009) Darwin's solution to the species problem. Synthese

Feder JL (1998) The apple maggot fly, Rhagoletis pomonella: flies in the face of conventional wisdom. In: Howard DJ (ed) Endless forms. Species and speciation. Oxford University Press, New York, pp 130-144

Fisher RA (1930) The genetical theory of natural selection. Clarendon Press, Oxford

Futuyma DJ (1986) Evolutionary biology, 2nd edn. Sinauer, Sunderland

Futuyma DJ (1998) Evolutionary biology, 3rd edn. Sinauer, Sunderland

Gavrilets S, Losos JB (2009) Adaptive radiation: contrasting theory with data. Science 323:732-737

Ghiselin MT (1969) The triumph of the Darwinian method. University of California Press, Berkeley

Ghiselin MT (1974) A radical solution to the species problem. Syst Zool 23:536-544

Ghiselin MT (2004a) Mayr on species concepts, categories and taxa. Ludus Vitalis 12:109-114

Ghiselin MT (2004b) Mayr and Bock versus Darwin on genealogical classification. J Zool Syst Evol Res 42:165-169

Goldschmidt RB (1940) The material basis of evolution. Yale University Press, New Haven

Gourbière S, Mallet J (2010) Are species real? The shape of the species boundary with exponential failure, reinforcement, and the "missing snowball". Evolution 64:1-24

Gray A (1888) Darwiniana: essays and reviews pertaining to Darwinism. D. Appleton and Company, New York

Gulick JT (1891) Divergent evolution through cumulative segregation. Smithsonian Rep 1891:273 
Gulick JT (1908) Isolation and selection in the evolution of species. The need of clear definitions. Am Nat 42:48-57

Haffer J (2007) Ornithology, evolution, and philosophy. The life and science of Ernst Mayr 1904-2005. Springer, Berlin

Haldane JBS (1932) The causes of evolution. Longmans, Green \& Co., London

Hamilton WD (1964) The genetical evolution of social behaviour. J Theor Biol 7:1-52

Hardy A (1965) The living stream. Collins, London

Hendry AP, Vamosi SM, Latham SJ, Heilbuth JC, Day T (2000) Questioning species realities. Conserv Genet 1:67-76

Hey J (2006) On the failure of modern species concepts. Trends Ecol Evol 21:447-450

Hull DL (1967) The metaphysics of evolution. Br J Hist Sci 3:309-337

Hull DL (1968) The operational imperative: sense and nonsense in operationism. Syst Zool 17:438-457

Jordan DS (1905a) The origin of species through isolation. Science 22:545-562

Jordan DS (1905b) Ontogenetic species and other species. Science 22:872-873

Jordan K (1905c) Der Gegensatz zwischen geographischer und nichtgeographischer Variation. Z Wissensch Zool 83:151-210

Judson HF (1996) The eighth day of creation. Makers of the revolution in biology. Twenty-fifth anniversary edition. Cold Spring Harbor Laboratory Press, Woodbury

Kitcher P (1984) Species. Philos Sci 51:308-333

Knapp S (2008) Species concepts and floras: what are species for? Biol J Linn Soc 95:17-25

Kohn D (2009) Darwin's keystone: the principle of divergence. In: Richards RJ, Ruse M (eds) The Cambridge companion to the "Origin of Species". Cambridge University Press, Cambridge, pp 87-108

Kottler MJ (1978) Charles Darwin's biological species concept and the theory of geographical speciation. The transmutation notebooks. Ann Sci 35:275-297

Krementsov NL (1994) Dobzhansky and Russian entomology: the origin of his ideas on species and speciation. In: Adams MB (ed) The evolution of Theodosius Dobzhansky. Princeton University Press, Princeton, pp 31-48

Lovejoy AO (1968a) The argument for organic evolution before The Origin of Species, 1830-1858. In: Glass B, Temkin O, Straus WL (eds) Forerunners of Darwin: 1745-1859. Johns Hopkins Press, Baltimore, pp 356-414

Lovejoy AO (1968b) Buffon and the problem of species. In: Glass B, Temkin O, Straus WL (eds) Forerunners of Darwin: 1745-1859. Johns Hopkins University Press, Baltimore, pp 84-113

Mallet J (1995) A species definition for the modern synthesis. Trends Ecol Evol 10:294-299

Mallet J (2001) The speciation revolution. J Evol Biol 14:887-888

Mallet J (2004) Poulton, Wallace and Jordan: how discoveries in Papilio butterflies initiated a new species concept 100 years ago. Syst Biodivers 1:441-452

Mallet J (2005) Speciation in the 21st century. Review of "Speciation", by Jerry A. Coyne \& H. Allen Orr. Heredity 95:105-109

Mallet J (2006) What has Drosophila genetics revealed about speciation? Trends Ecol Evol 21:386-393

Mallet J (2008a) Hybridization, ecological races, and the nature of species: empirical evidence for the ease of speciation. Philos Trans R Soc B 363:2971-2986

Mallet J (2008b) Mayr's view of Darwin: was Darwin wrong about speciation? Biol J Linn Soc 95:3-16

Mallet J (2008c) Wallace and the species concept of the early Darwinians. In: Smith CH, Beccaloni G (eds) Natural selection and beyond: the intellectual legacy of Alfred Russell Wallace. Oxford University Press, Oxford, pp 102-113

Mallet J (2009) Alfred Russel Wallace and the Darwinian species concept: his paper on the swallowtail butterflies (Papilionidae) of 1865. Gayana, Concepción, vol 73, No. 2, pp 42-54

Mallet J (2010) Group selection and the development of the biological species concept. Philos Trans R Soc B. doi:10.1098/rstb.2010.0040

Mallet J, Meyer A, Nosil P, Feder JL (2009) Space, sympatry, and speciation. J Evol Biol 22:2332-2341

Mayr E (1942) Systematics and the Origin of Species. Columbia University Press, New York

Mayr E (1947) Ecological factors in speciation. Evolution 1:263-288

Mayr E (1954) Change of genetic environment and evolution. In: Huxley J, Hardy AC, Ford EB (eds) Evolution as a process. Allen and Unwin, London, pp 157-180

Mayr E (1959) Isolation as an evolutionary factor. Proc Am Philos Soc 103:221-230

Mayr E (1963) Animal species and evolution. Harvard University Press, Cambridge 
Mayr E (1964) Introduction. In: Mayr E (ed) On the Origin of Species, by Charles Darwin. A facsimile of the first edition. Harvard University Press, Cambridge, pp vii-xxvii

Mayr E (1970) Populations, species, and evolution. Harvard University Press, Cambridge

Mayr E (1981) How I became a Darwinian. In: Mayr E, Provine WB (eds) The evolutionary synthesis. Perspectives on the unification of biology. Harvard University Press, Cambridge, pp 413-423

Mayr E (1982) The growth of biological thought. Diversity, evolution, and inheritance. Belknap, Cambridge

Mayr E (1992a) Controversies in retrospect. Oxf Surv Evol Biol 8:1-34

Mayr E (1992b) Darwin's principle of divergence. J Hist Biol 25:343-359

Mayr E (1999) Systematics and the Origin of Species, reprinted ed. Harvard University Press, Cambridge Mayr E (2002) Comments by Ernst Mayr. Theor Biosci 121:99-100

McOuat GR (1996) Species, rules and meaning: the politics of language and the ends of definitions in 19th century natural history. Stud Hist Philos Sci 27:473-519

Morgan TH (1919) A critique of the theory of evolution, 2nd edn. Princeton University Press, Princeton Orr HA (2009) Testing natural selection. Sci Am 44-51

Orr HA, Masly JP, Presgraves DC (2004) Speciation genes. Curr Opin Genet Dev 14:675-679

Paterson HEH (1985) The recognition concept of species. In: Vrba ES (ed) Species and speciation. Transvaal Museum, Pretoria, pp 21-29

Popper KR (1945) The open society and its enemies, 5th (1966) edn. Routledge, London

Popper KR (1972) Objective knowledge. An evolutionary approach. Oxford University Press, Oxford

Poulton EB (1904) What is a species? Proc Entomol Soc Lond 1903:1xxvii-cxvi

Price T (2008) Speciation in birds. Roberts \& Co., Greenwood Village

Pritchard JK, Stephens M, Donnelly P (2000) Inference of population structure using multilocus genotype data. Genetics 155:945-959

Provine WB (2001) The origins of theoretical population genetics. With a new afterword, 2nd edn. University of Chicago Press, Chicago

Reydon TAC (2004) Why does the species problem still persist? Bioessays 26:300-305

Reznick DN, Ricklefs RE (2009) Darwin's bridge between microevolution and macroevolution. Nature 457:837-842

Rice WR (1998) Intergenomic conflict, interlocus antagonistic coevolution, and the evolution of reproductive isolation. In: Howard DJ (ed) Endless forms. Species and speciation. Oxford University Press, New York, pp 261-270

Richards OW, Robson GC (1926) The species problem and evolution. Nature 117(345-347):382-384

Ritchie MG (2007) Sexual selection and speciation. Ann Rev Ecol Evol Syst 38:79-102

Robson GC (1928) The species problem. An introduction to the study of evolutionary divergence in natural populations. Oliver and Boyd, Edinburgh

Romanes GJ (1886) Physiological selection; an additional suggestion on the origin of species. J Linn Soc Lond (Zool) 19:337-411

Rothschild M (1983) Dear Lord Rothschild. Birds, butterflies and history. Hutchinson, London

Rundle HD, Nosil P (2005) Ecological speciation. Ecol Lett 8:336-352

Ruse M (1975) Darwin's debt to philosophy: an examination of the influence of the philosophical ideas of John F.W. Herschel and William Whewell on the development of Charles Darwin's theory of evolution. Stud Hist Philos Sci 6:159-181

Ruse M (1987) Biological species: natural kinds, individuals, or what? Br J Philos Sci 38:225-242

Schindewolf OH (1936) Paläontologie, Entwicklungslehre und Genetik. Kritik und Synthese. Bornträger, Berlin

Schluter D (2009) Evidence for ecological speciation and its alternative. Science 323:737-741

Seward AC (ed) (1909) Darwin and modern science. Essays in commemoration of the centenary of the birth of Charles Darwin and of the fiftieth anniversary of the publication of The Origin of Species. Cambridge University Press, Cambridge

Sloan PR (2009) Originating species. Darwin on the species problem. In: Richards RJ, Ruse M (eds) The Cambridge companion to the "Origin of Species". Cambridge University Press, Cambridge, pp 67-86

Smith AB (1994) Systematics and the fossil record. Documenting evolutionary patterns. Blackwell, Oxford

Smocovitis VB (1996) Unifying biology. The evolutionary synthesis and evolutionary biology. Princeton University Press, Princeton

Sokal RR, Crovello TJ (1970) The biological species concept: a critical evaluation. Am Nat 104:107-123 
Stamos DN (2006) Darwin and the nature of species. State University of New York Press, Albany

Stauffer RC (ed) (1975) Charles Darwin's natural selection. Being the second part of his Big species book written from 1856 to 1858 . Cambridge University Press, Cambridge

Stresemann E (1975) Ornithology. From Aristotle to the present. Harvard University Press, Cambridge

Sulloway FJ (1979) Geographic isolation in Darwin's thinking: the vicissitudes of a crucial idea. Stud Hist Biol 3:23-65

Wagner M (1873) The Darwinian theory and the law of the migration of organisms. Translation by J.L. Laird of a paper published in 1868. Edward Stanford, London

Wagner M (1889) Die Entstehung der Arten durch räumliche Sonderung. Gesammelte Aufsätze. Benno Schwabe, Basel

Wallace AR (1865) On the phenomena of variation and geographical distribution as illustrated by the Papilionidae of the Malayan region. Trans Linn Soc Lond 25:1-71

Wallace AR (1886) Romanes versus Darwin. An episode in the history of the evolution theory. Fortnightly Rev 300-316

Wallace AR (1889) Darwinism. An exposition of the theory of natural selection with some of its applications. Macmillan \& Co., London

Walsh BD (1864) On phytophagic varieties and phytophagic species. Proc Entomol Soc Philad 3:403-430

Williams GC (1966) Adaptation and natural selection: a critique of some current evolutionary thought, reissued with a new preface, 1996. Princeton University Press, Princeton

Williams GC (1992) Natural selection. Domains, levels and challenges. Oxford University Press, New York

Winsor MP (2006) The creation of the essentialism story: an exercise in metahistory. Hist Philos Life Sci 28:149-174

Wright S (1931) Evolution in Mendelian populations. Genetics 10:97-159

Wright S (1932) The roles of mutation, inbreeding, crossbreeding and selection in evolution. Proc XI Int Cong Genet Hague 1:356-366

Wright S (1978) Evolution and the genetics of populations. Volume 4. Variability between and among natural populations. University of Chicago Press, Chicago 